\title{
The Impact of the Imitation and Innovation Marketing in Services the Case of the Banks and Insurance
}

\author{
Mohamed Cherchem \\ Laboratory of Lameor, Faculty of Economic and Management, University of Oran, El M’Naouer, Algeria \\ Email: mcherchem@yahoo.fr
}

Received September 7, 2011; revised March 12, 2012; accepted March 19, 2012

\begin{abstract}
Under current conditions of competition, it becomes more and more risk for a bank or an insurance company not to innovate. Customers expect a steady stream of new products and services [1-3]. The competition will certainly do its best to satisfy those desires. Continuous innovation is the only strategic choice to avoid loss of market share, many studies claim that the prosecution and the blind imitation of competitors and neglect of clients are the underlying reasons for many failures of new financial products [4,5]. This paper presents a framework for innovation in financial services and the consequences of imitation in terms of innovations in financial services. The study was conducted in two parts: the first part focuses on the concepts of innovation in services and the creative process and the implications as well as marketing and organizational success factors and causes of failures of new banking products and services and insurance, through a guide 26 maintains direct interview questions to each manager (regional directors) of banking and insurance. This paper proposes to shed light on this issue.
\end{abstract}

Keywords: Innovation; Imitation and Services; Marketing

\section{Introduction}

Calvin L. Hadock, president of the American Marketing Association (AMA) says that the prosecution and the blind imitation of competitors and the neglect of clients are the root causes of many failures of new banking products and insurance [6].

Of many banks and insurance that adopt the strategy of imitation of copying promptly innovative banks, This is much easier in the banking and insurance because of the non-protection for innovations through patents experiencing failures. Note that in most cases, imitation of new products or services fail because they do not correspond to the needs or desires of customers (Badoc, M 1995, 1998 Peppers \& Rogers Lovelock, C 2005) [7-11].

Innovation bank can be protected. By definition, any bank or insurance can not protect the exclusivity of a product or process. Indeed, the banking products and services are intangible "Where they are held several consequences, they are not subject to wear and very little to obsolescence, Their aging is slow and may not be protected by patents, a new product can be quickly imitated by competitors; it is rather inconsistent from one institution to another, it is necessary to differentiate them. That is the true test of innovation lies in product differentiation from the competition." That is, the novelty is tangible and can be recognized and appreciated by the con- sumer. "That said the important thing is that the customer perceives a difference between a product or service offered by his institution and competing products and services and the gap that was filled for that one speaks truly innovative [12-20]."

In recent years there has been a stream of innovative products and banking and insurance that fit more with the new preferences and expectations of customers (Badoc, M 1995) [21-29]; the marketing is also called, more than ever, to play a decisive role and in this area. The innovation gives the bank the extent of its survival and vigor. It requires energy, imagination, creativity but also the direction of the market, its opportunities and its future. But this could be done through a strategic and operational effective marketing and strategy innovation [30-33].

\section{Review of the Literature}

Several researchers have studied and analyzed the success factors and causes of failures of innovations: AD Little (1997) Cooper (1979, 1982, 1993), studies of the PDMA (1993), Edgett, Shplay and Forbes (1992), The IEEP (1990), Booz, Allen and Hamilton (1982)...[34-36]. The results of these studies are consistent and demonstrate, poor assessment of market needs, lack of managerial skills including marketing, lack of communication, neglect of environmental problems [37-40], lack of flexi- 
bility in the organization, the growing number of financial institutions adopting the strategy of blind imitation which are among the most important causes of the failure of innovations. However, and contrary to these criteria, competence, experience and high marketing orientation, the market knowledge and screening, interaction with customers, the non-prosecution and not the blind imitation of competitors and non-negligent customers.... Count, however, among the most important factors in the success of innovations (Calvin L. Hadock. AMA 1979) $[5,12,13,31]$.

\subsection{The Conditions for Success of Financial Innovation}

The downstream processes including driving factors of successful innovation banking, does not in itself a successful global strategic approach to innovation. Other success factors must be analyzed and taken into account: ADLittle (1997), PDMA (1993), Edgett, Shiplay \& Forbes (1992), IEEP (1990), Hoddok CL (1990), BAH 1982), Cooper $(1982)$...[6,16,29,30]. We resume the main results that focus on three areas ranked in descending order of importance, namely:

\subsubsection{High Sensitivity and Attention to the Customer}

- The customer is considered the main source of ideas for new products. This marketing orientation contributes effectively to increase the chances of success of banking innovations.

- $\quad$ The cause of the failure of new banking products and services would it be a lack of sensitivity and attention to the client or the real needs? The Works of Brilman (1997), J. Ph. Deschamps \& P. Ranganath Nayak (1997), Peppers \& Rogers (1998), A. G. Vukonic \& R. Cooper (1991) and the method "Rubbermaid" rather give a positive answer yes to this question [19,31,34,].

\subsubsection{Adynamic Organization that Recognizes the Specificity of Banking and Directs It towards Innovation}

- The quality of the organization and management that determines the success of innovations, and this argument by action-oriented function of new products and services.

- The support and encouragement of senior management is a driving factor for the development and success of innovation.

- Innovation is the result of synergy and cross-functional interface between technicians, salespeople and customers to be successful [7,31,].

\subsubsection{Strengthening of Strategic Marketing in the Bank}

- Only by enhancing strategic thinking at the begin- ning of the innovation process we can hope to improve its effectiveness. Results of studies of $\mathrm{BAH}$ (1982), the PDMA (1990), Theys (1994) [7,14,40].

- Strengthen the strategic marketing strategies for specific innovation that is incremental innovation, whether of products or processes, can build a strategy of differentiation with specific Japanese firms have made a specialty known as "Kaizen" Japanese word that can be translated as "small steady progress" is to establish a strategy of differentiation through continuous innovation. Product and process are constantly being improved, so that the customer is always tempted to ask about new products and services introduced to the market, ever more efficient and more attractive. It is therefore cause the client in a spiraling demand for innovation and renewal more rapidly [34].

This strategy is differentiated by the fact that all competitors are not able to keep pace with the continuous innovation of "Kaizen". Note however, that innovation in banking and insurance, "Kaizen" is more easily adaptable by a bank or an insurance point we define innovation in terms of customers. Indeed, the difficulty of "Kaizen" is most evident in the continuity of the pace of innovation and continuity is even more difficult when the banking and insurance are opting for radical product innovations [31,32], or in banking and insurance, especially in innovation, it acts more on other marketing mix variables as the product itself. As a result, banks and insurance companies could sustain a pace of innovation continued acting primarily on the pricing policies, distribution or communication $[5,40]$.

\subsection{The Causes of Failure}

The causes of failure to launch new banking products and services are, therefore, the unlikable Previously Mentioned requirements for success. However, among the many findings from studies conducted on this subject, we retain the main causes of failed innovations. They focus on four areas classified by descending order of importance, namely:

\subsubsection{Adoption of the Strategy of Imitation}

Of the many banks and insurance companies that adopt the strategy to imitate what we call the new nicknames that are in reality copies or imitations, what Americans call "metooism" of copying promptly innovative banks. This is even easier in the banking and insurance because of the non-protection for innovations through patents experiencing a failure especially for small banks and insurance, It happens quite often that the copies are made of large banks and insurance companies that are slower to get under way, also prefer to observe the behavior of 
the novelty introduced by a competitor "smaller"; their marketing power is in fact sufficient to overcome their product, same time for that purpose financial institutions (banks and insurance) must also review and monitor products and product lines without competition to imitate them blindly $[25,34]$.

\subsubsection{Neglect of Environmental Issues}

Any banker or insurer before developing an innovation strategy must consider the environment. The banking and insurance the most attentive to its environment will probably be the better equipped to deal with the unexpected and therefore more able to offer products and services that best meet the real needs of customers. A bank that does not fully understand the needs and expectations of the market has little reason to be Quint, M (1991). So what if she tries to innovate. The analysis of the social and cultural environment of the bank is a necessary condition for successful innovation [27,34].

\subsubsection{An Underestimation of the Market and Competition}

Underestimating the competition, its location, speed and the increasing number of banks adopting the strategy of imitation, is also a major cause of failure of new products [12].

\subsubsection{Absence of a Predetermined Process of Innovation and Poor Organization of the Bank Hinder the Development and Success of Innovation}

- We must ensure consistency of the innovation process with the strategic objectives and skills, including marketing, cross-functional relationships should exist between the $\mathrm{R} \& \mathrm{D}$, and marketing between marketing and operations and commercial, etc... [15, 17].

- $\quad$ Poor overall organization of the banking and insurance or an organizational structure ill-suited to innovation or structural inertia and resistance to change $[22,40]$.

These are the main results emerged from the conceptual analysis in this theoretical framework.

The development of means of information and communication, the character more and more open of the Algerian economy, consciousness and the demand more or less enlightened consumer Algeria and the opening of the banking market stakeholders Foreigners may set the bar too high, especially in a potentially aggressive international competition under the Association Agreements of the European Union with Algeria also in the context of the accession of Algeria to the World Trade Organization (WTO). All these are factors that continue to disrupt or rather to revolutionize the classic work of Algerian pub- lic financial institutions. Banks and insurance Algerian public must organize, innovate and be responsive to their environment that has become very volatile and their demanding clientele. Financial innovation plays the role of this challenge particularly for our banks and insurance companies. Faced with this transition to this new market environment Algerian banking and insurance we offer these thoughts [20,34]:

- How the bankers and insurance Algerian public perceive the innovation and are sources of ideas for new products and services?

- The heads of banks and insurance Algerian public are they comprehensive studies on the Algerian bank customers?

\section{Research Methodology}

As part of the empirical study we conducted with bankers and insurance Algerian public (regional directors) in Oran, which are among 10 chosen as follows: BNA, BEA, CPA, BDL, BADR, PSC BANK, CAAR, SAA, CAAT, CRMA.

- $\quad$ The National Bank of Algeria (BNA).

- $\quad$ Le crédit Populaire d'Algérie (CPA).

- Popular Credit of Algeria (BEA).

- The Bank of Agriculture and Rural Development (BADR).

- $\quad$ The Bank of developments Local (BDL).

- The National Savings Fund and Provident Bank (CNEP Bank).

- $\quad$ Algerian Company of Transport Insurance (CAAT).

- The Algerian Company of Insurance and Reinsurance (CAAR).

- $\quad$ Algerian Insurance Company (SAA).

- Company of Reinsurance and Mutual Agricultural (CRMA).

We used in this study an interview guide of 26 questions by direct interview with each manager (regional directors) of banking and insurance. We have found this method more appropriate and effective in our case, given the small size of the sample and the opportunity to benefit from direct contact with the heads of banks and insurance companies selected. We chose this method is one of the most used marketing research, and it allows us to have satisfactory results such as:

- $\quad$ Simplicity to the respondent and the interviewer;

- It allows for spontaneous responses, thorough and credible;

- $\quad$ The ease of counting of responses;

- $\quad$ Make time compared to other research facilities.

After writing the questionnaire, it is essential to test them to check their understanding by respondents and potential improvements, the result was:

There were remarks of the officials interviewed who 
have been made regarding the numbers and percentages, which unfortunately we have not had, some questions have no answer because of confidentiality, and we noticed that certain responses were biased. This allowed us to redraft the questionnaire again; so we removed some and other issues we have simplified, we had the opportunity to add the necessary explanations to the understanding of each question.

These different banks and public assurances mentioned above will be the subject of our empirical research and the sample is selected from the Algerian banking market, knowing that there are other stakeholders (banks and foreign private insurance), like Baraka Bank, Societe Generale, Credit Paribas, Natexis Bank, Housing Bank, offering new banking products and insurance to individuals. The reason for which banks and foreign insurance and private were not addressed in our research is because they do not have a major influence on the results of our research with regard to the place of these Algerian economy in the past at the time of completion of the fieldwork.

Indeed, we study the perception of bankers and insurance Algerian public to innovations banking and insurance and are sources of ideas for new products and services and to know whether the customer is considered as the main source of ideas for new products and services? This study has revealed that attitude:

\section{Results}

If we try to summarize the results from the questionnaire to the heads of banks and insurance companies selected, we note the following:

1) The phenomenon of imitation and copying is widespread in the field of banking innovations, and the fact that the reaction and launch a new product comes the competition was cited by banks as an important factor in relation to customer needs, testimony and evidence, on the one hand, the passivity of the Algerian state-owned banks in terms of innovation. Indeed, the phenomenon of imitation and "copying" is widespread also in terms of sources of information for the launch of new banking products and services, and the fact that the source of the most important information to know the competition and internal sources in relation to customers and R \& D unit is cited by the majority of banks and insurance companies interviewed, shows, first the passivity of the banks in innovation and also the position of identical and indistinguishable, This attitude shows the poor organization of the civil new products within the banking and insurance Algerian public respondents, their innovation strategies and their arbitrary actions blindly imitating the banking and insurance neighboring or foreign, which would increase the risk of failure and incompatibility of new pro- ducts and services to customers and marketed.

2) The function R \& D and customers occupy the penultimate place as a source of ideas for new products, universities/research centers and research firms or consulting occupy the last place, while competitors and internal sources occupy all the first place, i.e. the Algerian public banks see them as the main sources of ideas for new products and services marketed, and therefore take precedence over the function R \& D customers. This paradox is another example of the passivity of the Algerian state-owned banks in terms of innovation and shows the narrow mindset marketing Bankers, Algerian and insurers and the poor organization of the function new products.

3) The main reason that prevents public banks is insurance is the rigidity in the bank and the regulations, consider the first main reasons that hamper banks' efforts in innovation. Factors "fear of failure and risks of innovation" are also considered as a major obstacle that may prevent a bank to innovate, This demonstrates again that banks and insurance Algerian government a passive attitude to innovation. If there is a fear of failure and the risk of innovation is because we are neither prepared nor organized in our strategic innovative, the management teaches us that the risk-taking among a manager is a quality leader ship is the main problem to face what the banks.

4) The majority of banks and insurance Algerian public has not an organizational structure that the success of new products and services.

5) None of the banks and insurance companies surveyed do not realize continuous and extensive studies on the behavior of bank customers. Almost all bank officials we interviewed, confirm the "lack of market information" and "lack of studies on customer" which are classified in third place and considered therefore as important as barriers that can prevent a bank or insurance to innovate. These major obstacles should be overcome, without knowing your market in general and especially its customers, banks can not act, especially in terms of innovation, or certainly not effectively.

6) All Algerian public banks are unable to estimate the cost. In addition, no bank has a system control and monitoring of new products and worse the majority of managers surveyed do not even remember the date of launch of new products. None of the banks and insurance companies polled does a communication strategy for products and services new and existing, specifies the objectives and overall marketing strategy of the bank. They use, most of the time, some conventional means of communication without any advertising positioning, or respecting pre-established plans of action. In all other banks surveyed are both in sponsorship as in other forms (sales promotion, direct marketing and public relations, adver- 
tising, mass media etc.). This explains why the banks and insurance companies interviewed consider the public policy of communication and promotion as a one-time expenditure, when they allow you they cyclical money available to make themselves known and not as a profitable investment, that is to say communication policy based on the event (sponsorship) and not the result of a strategic long-term.

7) Almost all banks and insurance Algerian public surveyed a sparse distribution network, the network of banks is described very thin. A network that is trained very small and very thin, which is, of course, a serious gap in the marketing of existing products and launching new products because they deserve more effort and resources to the growth and expansion of their networks to publicize the products and new services, knowing that most part of the marketing experts and researchers consider the extension and multiplication of the network as the centerpiece of any successful bank.

8) However, banks and insurance Algerian public indicate a number of actions including the launch of new products as well as the generalization of the system Télécompensation checks, installation of vending machines, in the various agencies and development agencies, some banks but this is still limited compared to what is done in foreign banks that turn on the Algerian market.

9) The direct marketing techniques in general, and mailing (e-mailing the contact via the internet with clients and between staff in different departments and services in particular directions Intranet and Extranet), are almost nonexistent in banking and insurance Algerian public. Despite the changing and increasing the market for information technology and communication (NTIC) in Algeria.

10) The majority of banks and insurance companies we interviewed, have problems of coordination and cooperation between different branches and "departments' information does not flow in time”, Moreover, banks and insurance companies seek to develop public policies for internal communication and eating that allow managers to agencies and branches and staff to adapt to unexpected situations.

\section{Conclusions}

An innovation strategy can be effective if it is surrounded by infrastructure development. Innovation in financial institutions (banking and insurance) and therefore requires prior conditions to its prosperity and success. Indeed, the banking and insurance continues to undergo several changes that make the banking and insurance Algerian government must develop a vision of their future by setting a marketing strategy that takes into account the new information environment and should in- clude a policy of innovation.

Indeed, on the one hand, strategic choices allow the banking and insurance to select a set of relational activities in order to maintain and foster relationships with customers, better to know, to satisfy its real needs, finally, to propose new products and services that meet their expectations and all changes that come into the world of banking and insurance. On the other hand, the marketing plan ensures consistency of thought marketing because it requires an ongoing review of new opportunities for product development and market changes and mutations in the environment and the optimal use of human resources, financial and material sources of the real success of any innovation policy, banking and insurance.

This means that the head of innovation, once informed by the various data and information collected through the panel to consider the objectives of the banking and insurance and specific objectives which will make its efforts to launch new banking products and services more efficient and rigorous.

Finally, innovation in a particular company in a bank is a diffuse process, collective, involving all business functions; other hand, this process must be extremely fast to take advantage of advance before being imitated by a competitor or otherwise catch up as quickly as a more innovative competitor.

\section{Limitations of the Research}

In any academic research, the results of this paper have limited because of lack of human and material resources and time constraints. For this reason, and as part of our study we hope that our research can be extended to other foreign commercial banks engaged in the Algerian market, to identify other outcomes and to be able to do analysis comparative. The sample could be expanded on integrating individual customers and customers' business could be considered parallel to that of individual customers.

\section{REFERENCES}

[1] F. Gallouj and P. Windrum, "Services and Services Innovation,” Journal of Evolutionary Economics, Vol. 19, No. 2, 2009, pp. 64-69.

[2] C. L. Hodock, "Stratégies behind the Winers and Losers," Journal of Businee Stratégy, Vol. 3, 1979, p. 38.

[3] C. Lovlock and D. Lapert, "Marketing Services,” Union Publishes, Paris, 1999.

[4] C. Lovlock, “Technology: Master or Slave of Service Delivery?” Décision Marketing, Vol. 8, 1996, p. 26.

[5] E. Métais and B. Moingeon, "Management of Innovation: Learning Mix,” French Review of Management, Vol. 133, 2001, pp. 43-46.

[6] F. Bilen and C. Sempels, "The Foundations of Services 
Marketing: A Critique and Development," French Review of Marketing, Vol. 212, 2007, p. 55.

[7] D. Peppers and M. Rogers, “The One to One. Enhance Your Customer Capital,” Editions of Organization, Paris, 1988.

[8] M. Zollinge, "Electronic Payments and Marketing," Vuibert Edition, Paris, 1989.

[9] M. Zollinger and E. Lamarque, "Marketing and Banking Strategies,” Edition Dunod, Paris, 1999.

[10] OCDE, "Policy Forum of Business and Industry on the Service Economy,” 1999.

[11] OCDE, "Innovation and Productivity in Services: Report of the Sydney Workshop Commission of the European Community,” 2001.

[12] F. Djellal and F. Gallouj, "Invisible Innovation and Hidden Performance in Services: A Challenge for Public Policy, Intereconomics," Review of European Economic Policy, Vol. 45, No. 5, 2010, pp. 278-283.

[13] P. Crance, "The Marketing Innovation Tools to Enhance Research and New Technologies," French Review of Marketing, Vol. 182, 2001, p. 125.

[14] P. Eiglier and E. Langeard, "Servuction," Ediscience Édition, Paris, 1994.

[15] M. Cherchem, "The Impact of Knowledge-Based Economy on the Development of Innovation in Services: Case of Algerian Banks and Insurance Companies,” Publication in IBIMA Business Review, Vol. 2011, 2011, Article ID: 631962.

[16] P. Kotler and B. Dubois, “The Marketing Management," Public Union, Paris, 2000.

[17] K. M. Murphy and W. C. Riddell, "Wages, Skills, and Technology in the United States and Canada," 1998. http://www.nber.org/papers/w6638

[18] P. Picoeur, "Services and Customer Satisfaction," French Review of Marketing, Vol. 144, 1993, pp. 47-50.

[19] M. Badoc, "Marketing Management for Financial Firms," Editions of Organization, Paris, 1995.

[20] M. Cherchem, "Innovation in Services as a Pillar of the Economy Based on Knowledge,” Journal of Management Sciences, No. 1-2, 2011, pp. 33-34.

[21] F. Gallouj and M. Savona, "Innovation in Services: A Review of the Debate and Perspectives for a Research Agenda," Journal of Evolutionary Economics, Vol. 19, No. 2, 2009, pp. 149-172. doi:10.1007/s00191-008-0126-4

[22] M. E. Mc Grath and M. Romeri, "From Experience: The R \& D Effectiveness Index: A Metric for Product Development Performance," Journal of Product Innovation Management, Vol. 11, No. 4, 1994, pp. 213-220.
[23] M. E. Porter, “Towards a Dynamic Theory of Strategy,” Strategic Management Journal, Vol. 12, 1991, pp. 95117.

[24] A. Munos, "Servuction, Procedures and Technology Cooperation,” Décision Marketing, Vol. 10, 1997, p. 57.

[25] F. Gallouj, "Services Innovation: Assimilation, Differentiation, Inversion and Integration," In: H. Bidgoli, Ed., The handbook of Technology Management, John Wiley and Sons, New York, 2010, pp. 989-1000.

[26] F. Djellal and F. Galloudj, “The Organization of the Innovation Process in Services: Results of a Survey Mailing,” Education \& Formation, Vol. 59, 2001, p. 9.

[27] F. Djellal and F. Gallouj, "Beyond Productivity Strategies in Services," Journal of Innovation Economics, Vol. 5, No. 1, 2010, pp. 89-104. doi:10.3917/jie.005.0089

[28] F. Djellal and F. Gallouj, "The Innovation Gap, the Performance Gap and the Policy Gap in Services,” In: F. Gallouj and F. Djellal, Eds., The Handbook of Innovation and Services, Edward Elgar Publishers, Cheltenham, 2010, pp. 635-675.

[29] N. Richard, "The Management Service, in Theory the Time Services,” Inter Edition, Paris, 1991.

[30] R. Durand, “The True Value of Innovation,” Expanssion management Review, Vol. 71, 2003, pp. 29-32.

[31] A. Seignour, "Internal Marketing: A State of the Art," Research and Applications in Marketing, Vol. 13, No. 3, 1998, pp. 48-51.

[32] F. Jallat, "Marketing Issues in Western Europe: Changes and Developments," International Business Press, New York, 2004.

[33] F. Jallat, "Innovation in Services: The Success Factor," Décision Marketing, 1994, p. 23.

[34] F. Jallat, "Yield Management, Dynamic Pricing and CRM in Telecommunications," Journal of Services Marketing, Vol. 22, No. 6, 2008, pp. 465-478. doi:10.1108/08876040810901882

[35] I. Ansoff, "Development Strategies of the Company," 5th Edition, Men \& Technical, Paris, 1984.

[36] F. Frery and J. Brostail, "Success and Failure in Research and Technology,” In: E.-Y. Grawshawr, Ed., The European Business, Belgym, Brussels, 1997.

[37] J. Gadrey, “The Service Economy,” Discovery, Paris, 1992.

[38] J. Lachmann, "Financing Strategies for Innovation," Economica, Paris, 1993.

[39] J. P. Flipo, “Automation Services: Technology Marketing,” Marketing Decisions, Vol. 14, 1998, pp. 72-79.

[40] M. Ingham, “Innovation: The Exception,” French Review of Management, Vol. 118, 2001, p. 76. 